J. Japan. Soc. Hort. Sci. 52(3) : 266-272. 1983

\title{
The Surface Wax of Several Grapes in Japan
}

\author{
Hiroshi Yamamura and Ryuji Naito \\ Fuculty of Agriculture, Shimane University, Matsue, Shimane, 690
}

\begin{abstract}
Summary
The amounts of the surface wax and its major component, the hard wax, of 'Delaware' grapes increased rapidly until 30 days after full bloom and made little change thereafter to the harvest time. On the contrary, the soft wax kept almost a constant level in the early stage of berry growth and increased steadily in the late stage. Further, with the advance of berry growth, a distinct change occurred in the composition of long-chain alcohols, the main components of the sof wax. These seasonal trends in the hard and soft waxes were similarly observed in both gibberellic acid (GA)-treated (seedless) and untreated (seeded) berries.

The accumulation of surface wax was inhibited in 'Delaware' when the postbloom GA application was late for the recommended time, 10 days after full bloom.

The amount of the surface wax was compared at maturity among 5 leading cultivars in Japan. 'Delaware', regardless of GA treatment, was highest in the amount of total and hard waxes, followed by 'Muscat Bailey A', 'Campbell Early', 'Kyoho' and 'Muscat of Alexandria', in this order. In the amount of soft wax, however, 'Campbell Early' was highest, followed by 'Kyoho', GA-treated 'Delaware', 'Muscat of Bailey A', GA-untreated 'Delaware' and 'Muscat of Alexandria', in this order.
\end{abstract}

\section{Introduction}

The external layer of grape berries is covered with a cuticle, the outer surface of which consists of overlapping platelets of wax, the so-called "bloom". Since this type of surface structure is a strong barrier to the transpiration from berries, the chemical nature and fine structure of the wax have been investigated by many workers in 'Thompson Seedless (Sultana)', the most extensively grown raisin grape in the world $(1,2,5,6,7,8,9,10,11)$. On the table grape cultivars, however, there have been hardly any detailed reports on them. The cuticular wax is known to be effective in protecting fresh grapes against water losses during transport and storage(5). Moreover, the table grapes which are rich in bloom are highly appreciated in Japan for their attractive appearance. Therefore, the research on the cuticle wax is thought to be equally important, in Japan, for the table grapes as well as for the raisin grapes.

\footnotetext{
1 Received for publication May 16, 1983
}

In the present study, the seasonal changes in quantity and quality of the surface wax were examined in 'Dalaware'. 'Delaware' is the most popular table grape in Japan, and most of the grapes on the market are seedless ones produced by GA treatment. Further, in several leading cultivars, a comparative study was conducted on the amount of the surface wax at maturity.

\section{Materials and Methods}

In 'Delaware', 5 to 10 bunches treated twice with GA in the ordinary manner (about 2 weeks before full bloom and 10 days after full bloom) for inducing seedless berries and the same numbers of untreated ones were sampled from a vine every 10 days after full bloom to maturity. Further, in order to clarify the effect of the time of postbloom GA application on the accumulation of surface wax, 10 bunches each, to which GA had been applied 5, 10, 15 or 20 days after full bloom were sampled from another vines of 'Delaware' at maturity. In addition, 10 bunches were sampled separately from 
vines of 'Campbell Early', 'Kyoho', 'Muscat Bailey $A$ ' and 'Muscat of Alexandria' at each maturity. All the bunches used in this study were harvested from the adult vines grown in the vineyard of Shimane University, Matsue, except for 'Muscat of Alexandria' grown in a greenhouse in the vineyard.

The procedure for the determination of quantity and composition of surface wax in these samples was as follows: Berries were removed from the bunches. The waxes were extracted at room temperature with petroleum ether and chloroform as suggested by Grncarevic and Radler(5) and Possingham et al. (8). Five hundred to 1,000 berries from 10 clusters in the early stages of berry growth and 120 to 200 berries from 5 to 6 clusters in the middle and late stages were used for the extractions. Berries were immersed in petroleum ether (b. p. $30 \sim 60^{\circ} \mathrm{C}$ ) 3 times each for $10 \mathrm{sec}$ (soft wax). After the petroleum ether was drained off, chloroform was added 3 times each for $10 \mathrm{sec}$ (hard wax). The extracts were evaporated to dryness using a rotary evaporator, and the remaining waxes were weighed after they had been dried overnight in a vacuum. The total surface area of berries used for an extraction was calculated from the diameter of individual berries, and the amounts of waxes were expressed as the weight per unit surface area of berries $\left(\mu \mathrm{g} / \mathrm{cm}^{2}\right)$. The soft and hard waxes were further analyzed by GLC(FID).

It has been shown that the greater part of grape wax is the hard wax, consisting mainly of oleanolic acid, and the soft wax is composed chiefly of long-chain alcohols together with smaller amounts of aldehydes, esters, fatty acids and hydrocarbons $(5,11)$. As we could not obtain the reagent of oleanolic acid, we used betulinic acid instead as a reference in GLC. Both compounds are the same in molecular weight and very close to each other in their molecular structures (Fig. 1). One mg of the hard wax was dissolved with $1 \mathrm{ml}$ of acetone, and methylated with diazomethane. Then, the acetone was evaporated, and the residue was dissolved in $1 \mathrm{ml}$ of acetone. Ten $u$ portion was injected into

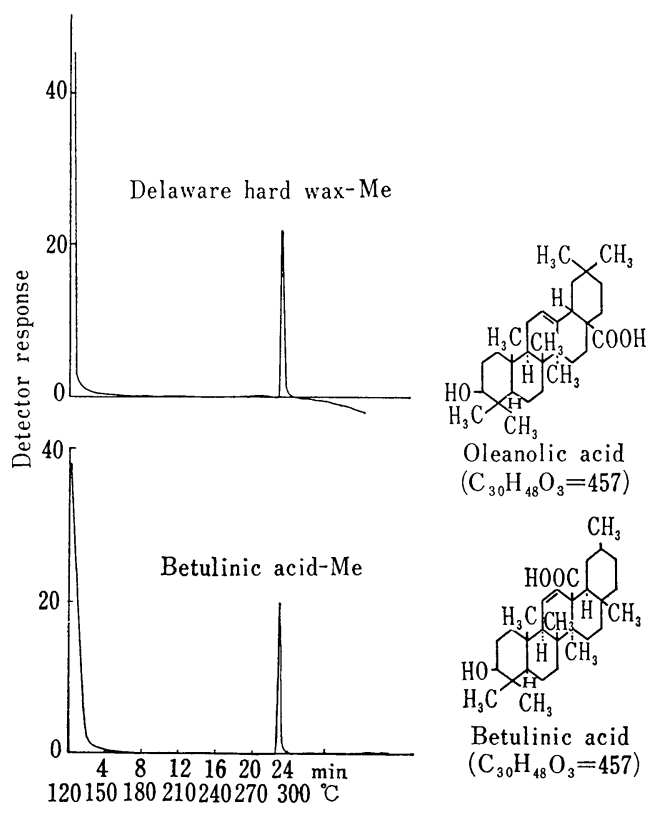

Fig. 1. GLC of the hard wax from 'Delaware' grape and betulinic acid (left), and the molecular structures of oleanolic acid and betulinic acids (right).

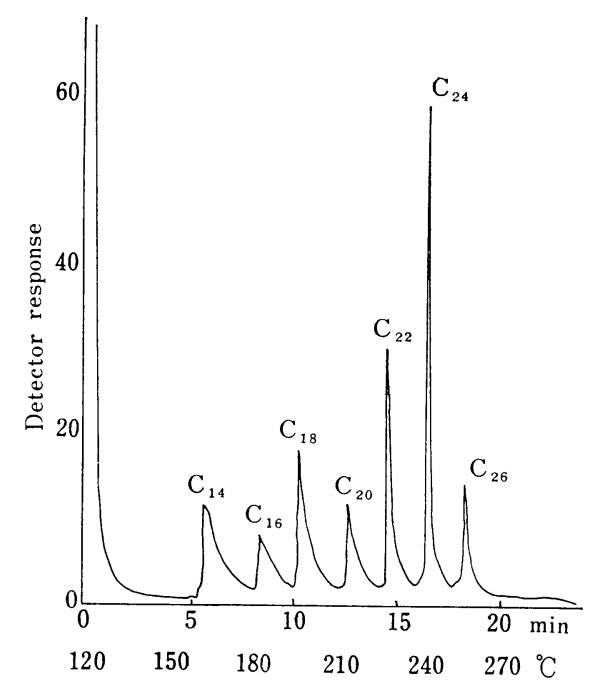

Fig. 2. Separation of long-chain alcohol mixtures by GLC. The numbers at the peaks indicate the chain-length of the corresponding alcohol. Column : $1.25 \% \mathrm{SE}-30$ on chromosorb W (80 100 mesh). Column temperature : $120^{\circ} \mathrm{C}$, linear temperature programing at $7.5^{\circ} \mathrm{C} / \mathrm{min}$ to 350 ${ }^{\circ} \mathrm{C}$. Injection temperature $: 360^{\circ} \mathrm{C}$. Nitrogen flow rate $: 40 \mathrm{ml} / \mathrm{min}$. 
GLC equipped with a $200 \times 0.2 \mathrm{~cm}$ stainless column packed with chromosorb w $(80 \sim 100$ mesh) coated with $1.25 \% \mathrm{SE}-30$. The temperature of the injector was $360^{\circ} \mathrm{C}$ and the column temperature was elevated from 120 to $200^{\circ} \mathrm{C}$. The carrier gas was nitrogen flowing at $40 \mathrm{ml} / \mathrm{min}$. The methylated hard wax of grapes exhibited only one peak in the chromatogram as shown in Fig. 1, the retention time of which coincided with that of betulinic acid. Accordingly, the amount of oleanolic acid expressed as the weight of betulinic acid was estimated from a standard curve in the 5 cultivars above indicated. In addition, the soft waxes extracted from the GA-treated (seedless) and untreated (seeded) 'Delaware' grapes sampled at various stages of berry growth were separated by GLC (FID) as described above. Long-chain alcohols with carbon numbers ranging from 14 to 26 were prepared for the reference in GLC (Fig. 2).

\section{Results}

The amount of surface wax in 'Delaware' changed drastically with berry growth. As shown in Fig. 3, the major part of the surface wax was the hard wax, in both the GA-treated and untreated berries, which increased rapidly with berry growth until 30 days after full bloom. However, such a remarkable change was not observed thereafter until harvest time. On the contrary, the amount of the soft wax kept almost a constant level until about 40 to 50 days after full bloom and it increased thereafter. The change with berry growth in the amount of total wax was almost the same with that of the hard wax, since the quantitative ratio of the soft wax to the hard one was very small. The seasonal changes in the hard wax differed little between GAtreated and untreated berries.

The soft wax of 'Delaware' was further examined by GLC for the long-chain alcohols which were reported to be its main components $(5,8)$. As shwon in Fig. 4 and 5 , the predominant alcohols were $n-C_{18}, n-C_{20}$, $\mathrm{n}-\mathrm{C}_{24}, \mathrm{n}-\mathrm{C}_{26}$ and unknown (presumably n$\mathrm{C}_{28}$ ) in both the GA-treated and untreated berries 10 days after full bloom. With berry growth, a distinct change occurred in the composition of the alcohols, i.e. 2 main components, $\mathrm{n}-\mathrm{C}_{18}$ and $\mathrm{n}-\mathrm{C}_{20}$ were not detected in the later stage.

Table 1 shows the effects of the time of postbloom GA application on the accumulation of the surface wax in 'Delaware' grape. The amount of soft wax was highest in GA application 5 days after full bloom, and decreased as the application was delayed, whereas the amount of hard wax was highest in GA application 10 days after full bloom, followed by those in applications 15 days, 5 days and 20 days after full bloom, in this order. It was observed that the berries GAtreated 20 days after full bloom were nonglaucous.

The amount of surface wax at maturity was compared among the 5 leading grape
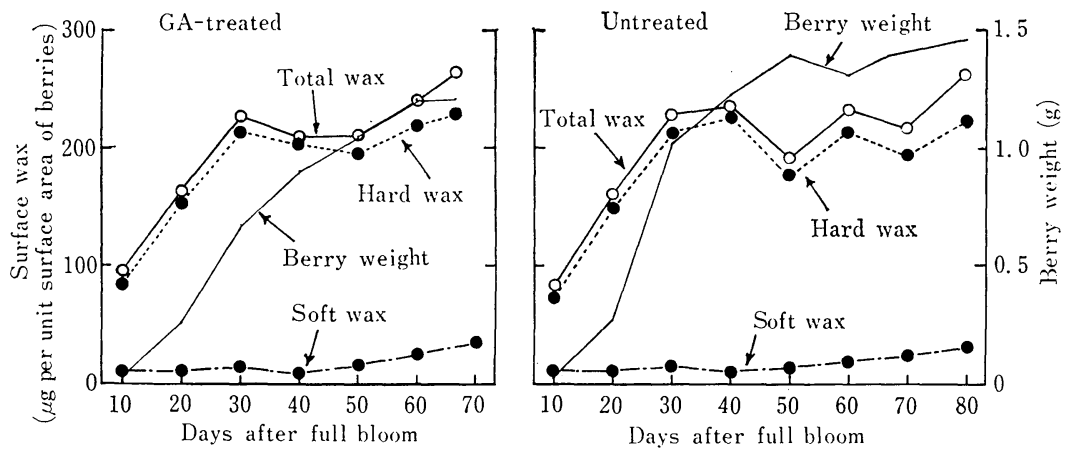

Fig. 3. Seasonal changes in the amounts of surface wax in GA-treated (seedless) and untreated (seeded) 'Delaware' grapes. 

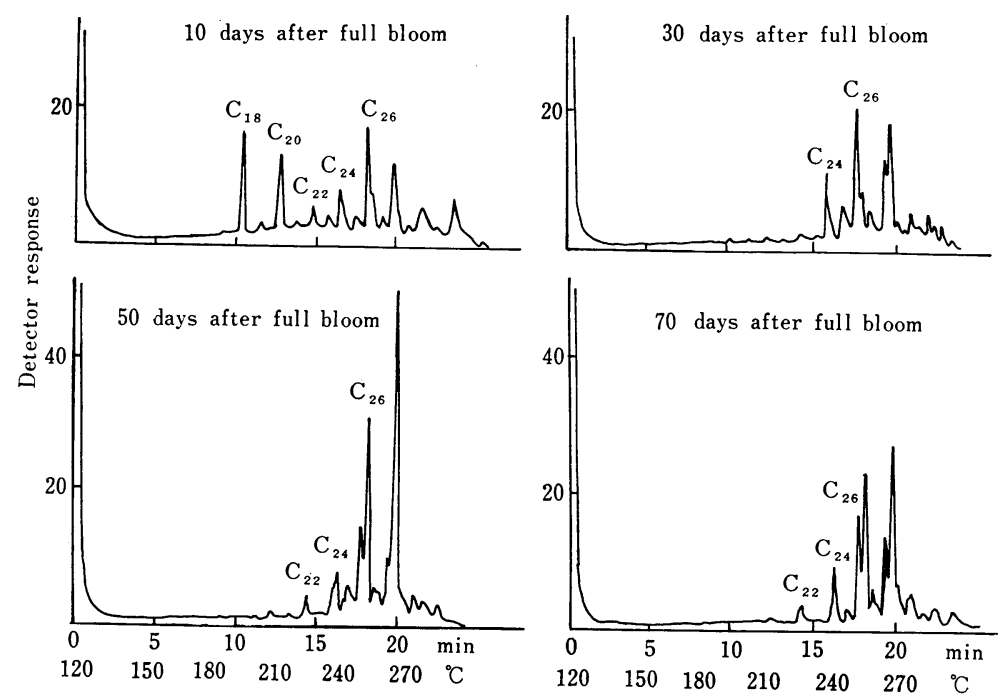

Fig. 4. Separation of the long-chain alcohols from the soft wax of GAtreated 'Delaware' grape by GLC. The amount of soft wax in jected : $40 \mu \mathrm{g} / 10 \mu \mathrm{l}$.

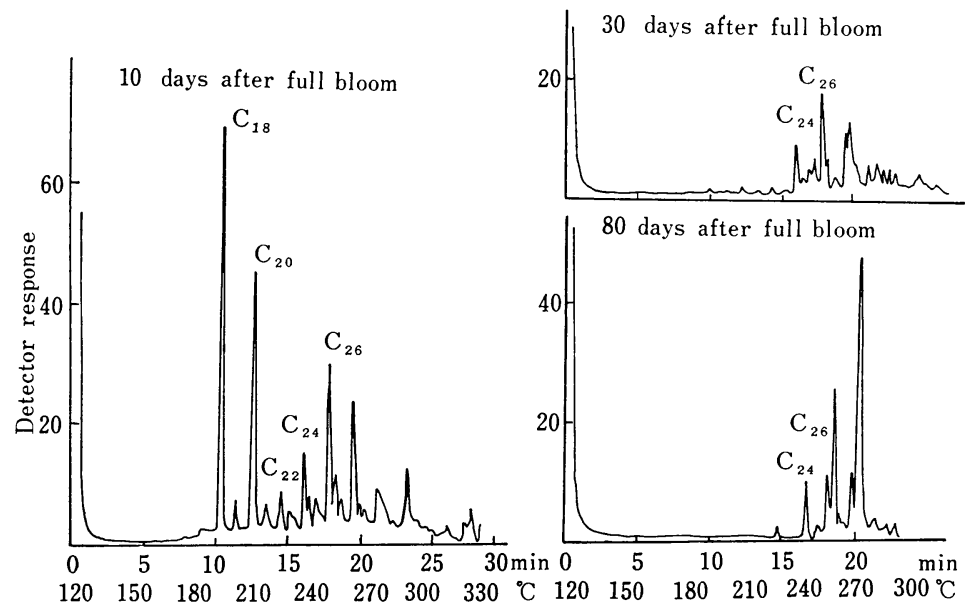

Fig. 5. Separation of the long-chain alcohols from the soft wax of GAuntreated 'Delaware' grape by GLC. The amount of soft wax in jected : $40 \mu \mathrm{g} / 10 \mu \mathrm{l}$.

cultivars. As shown in Table 2, 'Campbell Early' was highest in the amount of the soft wax, followed by 'Kyoho', GA-induced seedless 'Delaware', 'Muscat Bailey A', GAuntreated seeded 'Delaware' and 'Muscat of Alexandria', in this order. The amount of soft wax in 'Muscat of Alexandria' was only $41 \%$ of that in 'Campbell Early'. Concerning the hard wax, 'Delaware' exhibited the highest amount regardless of GA application, followed by 'Muscat Bailey A', 'Campbell
Early', 'Kyoho' and 'Muscat of Alexandria', in this order. Moreover, hard wax made up more than $80 \%$ of total wax in all the cultivars. The quantitative ratio of oleanolic acid to the hard wax varied consistently with cultivars; 'Kyoho' showed the highest rate $(88 \%)$ and 'Muscat of Alexandria' the lowest $(58 \%)$. The development of the waxy bloom observed visually on berry skin in each cultivar was related to some extent to the amount of the soft wax. 
Table 1. Effect of the time of postbloom GA application on the amount ${ }^{\mathbf{z}}$ of surface wax at maturity in 'Delaware' grape.

Time of GA application Soft wax Hard wax Total wax (Days after full bloom)

\begin{tabular}{rlll}
5 & 31 & 186 & 217 \\
10 & 30 & 197 & 227 \\
15 & 28 & 188 & 216 \\
20 & 27 & 175 & 202 \\
\hline
\end{tabular}

$z: \mu g$ per unit surface area of berries.

Table 2. Comparison of the amount ${ }^{z}$ of surface wax at maturity among the 5 leading cultivars in Japan.

\begin{tabular}{|c|c|c|c|}
\hline Cultivar & Soft wax & Hard wax & Total wax \\
\hline $\begin{array}{l}\text { Delaware } \\
\text { (GA treated) }\end{array}$ & 35 & $228(165)^{\mathrm{y}}$ & 263 \\
\hline $\begin{array}{l}\text { Delaware } \\
\text { (GA untreated) }\end{array}$ & 31 & $232(191)$ & 263 \\
\hline Campbell Early & 46 & $203(162)$ & 249 \\
\hline Kyoho & 38 & $142(125)$ & 180 \\
\hline Muscat Bailey A & 33 & $214(158)$ & 247 \\
\hline Muscat of Alexandria & 19 & $101(59)$ & 120 \\
\hline
\end{tabular}

\section{Discussion}

The surface wax of grape berries in 'Delaware', similar to that in 'Thompson Seedless' reported by Grncarevic and Radler (5), consisted mainly of hard wax, which is soluble in chloroform but insoluble in petroleum ether. The amounts of both the hard wax and the total waxes in 'Delaware' increased rapidly with berry growth until 30 days after full bloom and kept almost a constant level thereafter. Radler(10) has reported, however, that no considerable change was observed in the amount of surface wax (total wax) during berry growth in 'Thompson Seedless'. It is not clear whether the disagreement of Radler's results with ours is caused by the differences in cultivars, in climatic conditions, or in both. The soft wax, which is soluble in petroleum ether and only a minor component of the surface wax, showed hardly any quantitative change in the young stage of berries though it increased from 40 days after full bloom to maturity. Further, the composition of longchain alcohols, the major components of soft wax, was found to vary with berry growth, i. e. the quantitative ratio of alcohols having larger numbers of carbons $\left(n-C_{24}, n-C_{26}\right.$ and unknown, which is presumably $\mathrm{n}-\mathrm{C}_{28}$ according to its retention time on the chromatogram) became higher with berry growth. In addition, the composition of the alcohols at maturity in 'Delaware' is similar to that of the 'Thompson Seedless' reported by Radler (10) but the predominant alcohol differs between the 2 cultivars, thus being an unknown $\mathrm{C}$ presumably $\mathrm{n}-\mathrm{C}_{28}$ in 'Delaware' vs. $\mathrm{n}-\mathrm{C}_{26}$ in 'Thompson Seedless'. It is assumed that the quantitative and qualitative changes of the soft wax during berry growth observed in this study may affect the water permeability of grape skin as suggested by Possingham et al. (8) and Radler (9).

In Japan, most of 'Delaware' are sold in markets as seedless ones which are produced by means of the GA-application. This is the reason why, in this study with 'Delaware', the GA-treated berries were compared with GA-untreated ones. Between them, however, little changes with berry growth in the amounts of the hard and total waxes were observed.

In the ordinary manner of producing the seedless 'Delaware' grape, GA is applied twice, about 2 weeks before and 10 days after full bloom. When the postbloom GA application was late for the recommended time, 10 days after full bloom, the berries became poor in the waxy bloom and appeared less surface wax. This trend was particularly obvious when GA was applied 20 days after full bloom. Flore and $\operatorname{Bukovac}(3,4)$ have shown that the production of epicuticle wax by expanding leaves of cabbage is inhibited by a pesticide, EPTC, and this inhibition is accompanied by the absence of waxy bloom and the reduction of surface fine structure. On the other hand, Possingham et al. (8) have described that the spray of fungicides containing detergents affects the wax structure. The precise reason for the reduction of the surface wax by the delay of postbloom GA application in this study is not clear but it seems that a detergent, Aerol OP contained in the GA solution may play a 
role in its reduction.

When the amount of surface wax was compared among 5 leading cultivars, 3 of 4 cultivars of Vitis labruscana Bailey ('Delaware', 'Campbell Early' and 'Muscat Bailey A', with exception of 'Kyoho') contained total wax more than 2 times higher than 'Muscat of Alexandria', a cultivar of Vitis vinifera Linn., the wax amount of which was $120 \mu \mathrm{g}$ per $\mathrm{cm}^{2}$. According to Grncarevic and Radler(5) and Possingham(8), the amount of total surface wax in 'Thompson Seedless' (Vitis vinifera LINN) is about 100 $\mu \mathrm{g}$ per $\mathrm{cm}^{2}$ which is almost equal to that of 'Muscat of Alexandria' in this study. Thus it is interesting to note that a great difference in the amount of the surface wax exists between $V$. vinifera and $V$. labruscana. Whether or not it is related to the specific difference (V.vinifera: V.labrusca) per se, however, remains to be examined further. According to the visual observation of berries, 'Campbell Early' was highest in bloom and 'Muscat of Alexandria' was lowest. The same relation between them was found in the amount of soft wax but not in that of hard one. Further study should be necessary to get a conclusion on this matter, but it seems that the development of bloom may be connected more to the deposition of soft wax than that of hard one.

\section{Acknowledgement}

The authors are greatly indebted to Messers. Yasuhiro Fukuhara and Ryoji Yano for their assistance in conducting the present experiment.

\section{Literature Cited}

1. Chamber, T. C. and J. V. POSSINGHAM. 1963.
Studies of the fine structure of the wax layer of sultana grapes. Aust. J. Biol. Sci. $16: 818-825$.

2. DUMman, W. F. and M. GRNCAREviC. 1962. Determination of the surface waxy substances of grapes. J. Sci. Food Agric. $13: 221-224$.

3. Flore, J. A. and M. J. BuKOVAC. 1974. Pesticide effects on the plant cuticle. I. Response of Brassica oleracea L. to EPTC as indexed by epicuticular wax production. J. Amer. Soc. Hort. Sci. $99: 34-37$.

4. Flore, J. A. and M. J. Bukovac. 1976. Pesticide effects on the plant cuticle II. EPTC effects on leaf cuticle morphology and composition in Brassica oleracea L. J. Amer. Soc. Hort. Sci. 101 : 586-590.

5. GRNCAREVIC, M. and F. RADLER. 1971. A review of the surface lipids of grapes and their importance in the drying process. Amer. J. Enol. Vitic. $22: 80-86$.

6. MARKLEY, K.S., C. E. SANDO and S. B. HENDRICKS. 1938. Petroleum ether-soluble constituents of grape pomace. J. Biol. Chem. $123: 641-654$.

7. Possingham, J. V. 1972. Surface wax structure in fresh and dried sultana grapes. Ann. Bot. $36: 993-996$.

8. Possingham, J. V, T. C. Chambers, F. Radler and M. GRNCAREVIC. 1967. Cuticular transpiration and wax structure and composition of leaves and fruit of Vitis vinifera. Aust. J. Biol. Sci. $20: 1149-1153$.

9. RADLER, F. 1965. Reduction of loss of moisture by the cuticle wax components of grapes. Nature $207:$ 1002-1003.

10. RADLER, F. 1965. The surface waxes of the sultana vine (Vitis vinfera cv. Thompson Seedless). Aust. J. Biol. Sci. 18:10541056.

11. RADLER, F. and D. H. S. HORN. 1965. The composition of grape cuticle wax. Aust. J. Chem. $18:$ 1059-1069. 


\title{
本邦主要ブドウ品種の果皮ワックスについて
}

山村 宏 -内藤隆次

島根大学農学部 690 島根県松江市西川津町 1060

\begin{abstract}
摘 要
デラウェア果粒の表皮ワックスは, 硬質ワックスが大 部分を占め, 果粒の単位面積当たりの全ワックス, 硬質 ワックス量はともに満開後30日まで急激に増加し, その 後は収穫時まで大きな変化は認められなかった。一方, 軟質ワックスは果粒の発育初期には一定レベルを維持 し, 発育後期には徐々に増加した。 また, 軟質ワックス の主成分である長鎖アルコールの組成は，果粒の発育と ともに明らかな变化がみられた．硬質ワックスと軟質ワ ックスの含量や組成の変化は GA 処理無核果, 無処理有 核果の両者で同様の傾向が認められた。 ‘デラウェア’に お壮るGA の開花後処理が，適期である満開後10日より

遅くなると，果皮ワックスの形成が抑制された． わが国の主要ブドウ 5 品種の果皮ワックス量を成熟時 に比較した. 全ワックス量と硬質ワックス量ともに, ‘デラウェア’が GA 処理, 無処理にかかわらず, 最も 高く, 次いで'マスカット・ベーリーA', ‘キャンベル・ アーリー’, ‘巨峰’, ‘マスカット・オブ・アレキサンド リア’の順に低かった. 一方, 軟質ワックス量は“キャ ンベル・アーリー’が最も高く, 次いで ‘巨峰’, 以下 GA 処理 ‘デラウェア’, ‘マスカット・ベーリーA', GA 無処理 ‘デラウェア’, ‘マスカット・オブ・アレキサン ドリア’の順であった.
\end{abstract}

